\title{
O CADERNO ESCOLAR COMO OBJETO DE ESTUDO: UMA APROXIMAÇÃO DOS AVANÇOS METODOLÓGICOS EM MANUALÍSTICA ${ }^{1}$
}

\author{
EL CUADERNO ESCOLAR COMO OBJETO DE ESTUDIO: UNA \\ APROXIMACIÓN A LOS AVANCES METODOLÓGICOS EN MANUALÍSTICA
}

\author{
THE SCHOOL EXERCISE BOOK AS AN OBJECT OF STUDY: AN \\ APPROACH TO METHODOLOGICAL PROGRESS IN TEXTBOOK RESEARCH
}

Kira Mahamud ${ }^{2}$ Ana Maria Badanelli ${ }^{3}$

\begin{abstract}
Resumo
O artigo aborda questões em torno dos contextos de transmissão e recepção dos conteúdos dos livros didáticos, tendo como objeto de estudo o caderno escolar. $\mathrm{O}$ recorte temporal delimita-se entre 1930 e 1950, no contexto espanhol. Considerando que a mensagem do livro se aproxima daquilo que se queria ensinar em um determinado momento histórico, o grande desafio é perceber como os receptores, ou seja, os alunos, receberam a mensagem contida no livro. Para isso utiliza o caderno escolar como fonte e extensão dos livros didáticos para se aproximar das representações feitas por eles. A pesquisa analisa os diários de classes, também chamados de cadernos rotativos, cadernos individuais e cadernos de deveres, e conclui que não basta considerar o livro didático como instrumento de conteúdos, mas conectar outras fontes para se adentrar na produção escolar real.
\end{abstract}

PALAVRAS-CHAVE: História da Educação. Livros Didáticos. Cadernos Escolares.

\section{Resumen}

El artículo aborda la cuestión de los contextos de transmisión y recepción de los contenidos de los manuales escolares, teniendo como objeto de estudio el cuaderno escolar. El recorte temporal se delimita entre 1930 y 1950, en el contexto español. Considerando que los contenidos del manual constituyen el conocimiento que se quería enseñar en un determinado momento histórico, el gran desafío es descubrir cómo los receptores, es decir, los alumnos, recibieron y trabajaron esos contenidos. Se utiliza el cuaderno escolar como fuente y extensión de los manuales para acercarnos a las representaciones del conocimiento transmitido en los libros de texto realizadas por los estudiantes como trabajo escolar y deberes. La investigación analiza los diarios de clases, también llamados cuadernos rotativos, cuadernos individuales y cuadernos de deberes, y concluye que no se debe analizar el libro de texto de forma aislada como

\footnotetext{
${ }^{1}$ N.T.: Traduzido para o português por Blanca Shung Luen Menezes Li. Versão em espanhol intitulada "El cuaderno escolar como objeto de estudio: una aproximación a los avances metodológicos en manualística" e publicada como capítulo no livro: "La historia de la cultura escolar en Italia y en Espana: balance y perspectivas", organizado por Meda e Badanelli (2013).

${ }^{2}$ Kira Mahamud, UNED, Juan del Rosal 40, Facultad de Educación, kmahamud@edu.uned.es.

${ }^{3}$ Ana Maria Badanelli UNED, Juan del Rosal 40, Facultad de Educación, abadanelli@edu.uned.es.
} 
vehículo de contenidos, sino conectarlo con otras fuentes que permitan comprender el grado de procesamiento de dicho conocimiento. El estudio de la producción escolar real es una vía.

PALABRAS CLAVE: Historia de la Educación. Manuales Escolares. Cuadernos Escolares.

\begin{abstract}
The article deals with the issue of the contexts of transmission and reception of the contents of textbooks, turning our attention to the school exercise book as object of study, between 1930 and 1950, in Spain. Considering that textbooks' contents constitute the knowledge selected to be taught at a particular historical moment, the great challenge is to discover how the receivers, that is to say, the students, received and worked those textbooks' contents. The school exercise book is thus employed as a source and extension of the textbook that allows the researcher to get closer to the representations of the knowledge transmitted in the textbooks made by the students as class and homework. The research analyzes class diaries, also called rotating exercise books, individual exercise books and homework exercise books, and concludes that textbooks should not be analyzed isolated as vehicles of knowledge, but connected to other sources that allow to understand the degree of processing of such knowledge. The study of real school production is one the paths.
\end{abstract}

KEYWORDS: History of Education. School Textbooks. School Exercise Books.

\title{
INTRODUÇÃO
}

Desde a década de oitenta do século passado foi se produzindo uma mudança no campo da história da educação com importantes repercussões, renovando as linhas de pesquisa empreendidas, assim como os enfoques e métodos utilizados para desenvolvêlas. Uma das perspectivas emergentes, que se tem dado cada vez mais atenção, é a chamada história interna da educação. Porém, a atividade educativa é, frequentemente, volátil e não deixa muitos vestígios documentais como desejariam os historiadores. Os que tem buscado conhecer, com rigor, esse campo, tem comprovado as enormes dificuldades em que geralmente tropeça o pesquisador, vendo-se obrigado a utilizar fontes parciais e indiretas, quando não a realizar um verdadeiro trabalho de arqueologia escolar.

Uma das mais importantes fontes históricas de que dispomos é o conjunto de livros usados nas instituições educacionais: os manuais/livros escolares ${ }^{4}$. O manual escolar tornou-se, nos últimos anos, uma fonte privilegiada para historiadores do livro e para historiadores da educação. Ao redor deles surgiu um novo campo de conhecimento dotado de entidade própria; são parte integrante do património histórico-educacional, não apenas como objetos depositários da memória individual e coletiva, mas também por constituir uma fonte imprescindível para a pesquisa acerca da cultura escolar, além de produtos cobiçados pela política e pelo mercado.

\footnotetext{
${ }^{4}$ N.T.: Neste artigo, os termos manual, manual escolar, manual didático, livro didático, serão usados como sinônimos.
} 
Não obstante, o fato de os livros didáticos ocuparem hoje um lugar central no conhecimento da distribuição dos saberes no âmbito dos sistemas de ensino não significa que deixe de ser um objeto complexo e de difícil precisão conceitual. Especialmente quando queremos nos aprofundar nos processos de ensino $\mathrm{e}$ aprendizagem que durante muitos anos ocorriam sob o que Frank Simon e Mark Depaepe denominaram "chalkface", o domínio do giz (DEPAEPE; SIMON, 2005, p. 337).

Parafraseando Somoza, a investigação sobre o "objeto" manual escolar corre o risco de começar a circundar sobre um determinado conjunto de aspectos que se referem ao momento de produção e de emissão da mensagem ou à comunicação (análise de conteúdo ideológico, político, científico, didático, das políticas educacionais, das práticas comerciais e editoriais, etc.) e esquecer ou menosprezar outros aspectos, como:

1) o momento e as condições da recepção da mensagem (a situação política, cultural , a aproximação ou distanciamento aos movimentos de opinião da sociedade);

2) o tipo de influência que exerce nos receptores (intensa, instável, persistente, ocasional, etc.);

3) as ações que os receptores desenvolvem frente a mensagem escolar e institucional (cujas extremidades seriam a aceitação devota e a rejeição frontal) e, definitivamente, o papel que os livros escolares e o currículo desempenharam - e continuam desempenhando - no processo de socialização das gerações, atendendo suas variações segundo as épocas históricas, o desenvolvimento das tecnologias (particularmente as da comunicação) e as tendências gerais do sistema social (SOMOZA RODRÍGUEZ, 2006).

Podemos afirmar que os livros escolares contem a concretização do currículo prescrito, o que os converte em uma fonte primordial para conhecer e analisar as intenções, os propósitos, as finalidades que as autoridades buscavam e propunham como objetivos educacionais. Respondem à pergunta em torno do que se queria ensinar em uma determinada época histórica. Portanto, no complexo sistema de comunicação do mundo educativo, são fontes que oferecem informações sobre o emissor da mensagem, sobre aquele de quem procede a mensagem. Nos mostra as intenções dos encarregados de codificar a mensagem, e de transmiti-la através de um canal ou meio, neste caso, o texto escolar, até um receptor, preceptor e/ou observador: o aluno. Através deles é possível decifrar o código em que a mensagem é escrita, quais são seus signos e suas regras, como está organizado e, claro, podemos analisar o canal, o meio físico por meio do qual se transmite a comunicação, ou seja, as materialidades do texto escolar e as possibilidades que estas materialidades oferecem ou não ao processo de ensinoaprendizagem.

No entanto, por si só, os livros didáticos/manuais não podem revelar as mensagens que recebe o receptor nem como ele as trabalha, coleta e decodifica. Não podemos estudar como o receptor principal (porque existem outros receptores como o professor e a família) interpreta o que o emissor quer dar a conhecer, os conteúdos que possui o manual. Por meio da análise do manual não podemos concluir sobre como o professor transmite a mensagem, como o receptor trabalha e decodifica a mesma mensagem adaptado pela intermediação e que tipo de resposta proporciona diante dele. As palavras de Elsie Rockwell nos servem para evidenciar a limitação principal desta fonte: "por trás da imagem da escola que se pode evocar ao examinar os livros 
escolares, há uma complexa história da prática real em sala de aula" (ROCKWEEL, 2004, p. 327).

Para ajudar a minimizar este problema, propomos, em vez de um uso exclusivo do manual didático como fonte primária de pesquisa, uma extensão de objeto de estudo dentro da produção escolar, dentro do conjunto de fontes que recorrem ao trabalho escrito feito pelos alunos, plasmados essencialmente sobre papel em uma variedade de suportes ou produtos finais como são os exames, as folhas soltas ${ }^{5}$, os livros ativos ${ }^{6}$ e os diferentes tipos de cadernos escolares. Neste trabalho nos concentramos no último tipo de suporte, o chamado caderno escolar.

Há alguns anos começou um movimento historiográfico que utilizava os cadernos escolares como fonte para o conhecimento da "caixa preta" da educação, em sala de aula (VIÑAO FRAGO, 2006). Foram utilizados para analisar a transmissão e inculcação do imaginário e a representação social e escolar da própria infância, da escola, da família e de outros temas similares (ANDRÉS, 2005; ANDRÉS; ZAMORA, 2001; EaD, 2003; EaD, 2008; EaD, 2010). Emergem como instrumentos de aculturação do escrito, como veículos transmissores de conhecimentos, valores, atitudes e sentimentos, como meio para o estudo do currículo, das diferentes disciplinas e atividades escolares e como um instrumento de expressão pessoal e subjetiva do aluno.

O Centro de Pesquisa MANES participa no estudo destas fontes, utilizando-as como complemento à pesquisa com textos escolares. Os principais objetivos da pesquisa com cadernos que contribuem para a pesquisa manualística são três:

1) detectar e reconhecer quais manuais escolares foram realmente utilizados (o que garante sua representatividade e poder de influência);

2) descobrir a forma em que o professor faz uso do manual através do trabalho escolar de seus alunos (o qual nos leva a compreender melhor o trabalho docente do professor);

3) examinar os conteúdos trabalhados por meio da linguagem escrita verbal e icônica. Em definitivo, o seguimento da pista dos manuais nos cadernos trata de explicar uma das questões mais polêmicas dentro da manualística: a questão metodológica de seu uso.

\section{A variedade das fontes relacionadas com a produção escolar}

Os últimos estudos sobre manualística coincidem e enfatizam a necessidade de contextualizar os manuais escolares dentro de suas diversas áreas contextuais (HEINE, 2010), combinando-os com outras fontes (DEPAEPE; SIMON, 2003, 2005) e incorporando na análise o estudo das produções escritas infantis (BECCHI, 2005; EaD, 2005).

O trabalho escolar pode ser encontrado em diversos formatos e cada estudo deve buscar aqueles que melhor respondam às perguntas de sua pesquisa. $\mathrm{O}$ caderno escolar não é a única fonte que nos permite aproximar dos trabalhos escolares. Os exames por exemplo nos permitem avançar um passo a mais desde a intencionalidade que tem os

\footnotetext{
${ }^{5}$ Hoje em dia é frequente o uso de material fotocopiado pelos professores: folhas soltas com exercícios.

${ }^{6} \mathrm{O}$ Centro de Pesquisa MANES conceitua o livro de texto ativo como aquele em que o aluno pode e deve realizar os exercícios dentro do mesmo livro que lhe serve de manual.
} 
manuais até a recepção da mensagem que eles transmitem. Apropriadamente Viñao Frago tem chamado a atenção sobre a invisibilidade do exame para referir-se à reduzida aparição deste tema nos estudos sobre educação e sua escassa presença na documentação do ensino (VIÑAO FRAGO, 2001); o que contrasta com a importância que de fato tem e teve na vida cotidiana das salas de aula.

Um dos pontos em que a política educacional adquire concretização é, precisamente, o problema do exame. É observado pelos responsáveis da política educacional, pelos diretores das instituições escolares, pelos pais de família, pelos alunos e finalmente pelos próprios docentes. Embora cada grupo social possa ter a sua representação em relação ao papel que ocupa o exame, todos esses grupos coincidem em termos globais em esperar que por meio do exame se obtenha um conhecimento "objetivo" sobre o saber de cada estudante (BARRIGA, 1994).

O exame influi nas práticas escolares, boa parte do que ocorre em sala de aula e fora dela - tem o exame como referência. Os exames que também possuem limitações metodológicas (não indicam, por exemplo, que conhecimentos e aprendizagens perduram depois), sem dúvida, são uma fonte que revelam aqueles conteúdos dos manuais escolares que deviam aprender os alunos, especialmente em épocas em que o tipo de educação oferecida era excessivamente de memorização e competição. Considerando que os exames tiveram uma função de controle, destinada tanto aos alunos como aos professores, e considerando também as mudanças políticas que em cada época afetam o seu desenvolvimento, - a atribuição de notas (qualificações) ao trabalho escolar é uma herança do século XIX, coincidentemente quando aparecem os textos escolares -, a análise dos conteúdos levados a exame e como se exige que sejam aprendidos pode nos ajudar a esclarecer, não só quais manuais foram utilizados, e quais conteúdos, mas também como eles foram utilizados. Não nos esqueçamos, que a maneira de perguntar os conteúdos em um exame, determina a forma de abordar o estudo de tais conteúdos e o modo de corrigir, indica o que o professor considera mais relevante na aprendizagem.

Os exames indicam quais são os mecanismos de determinação do conhecimento que é considerado de alto status, valioso, etc. As exigências dos exames são aquelas que outorgam o qualificativo de importante aos vários conteúdos que aparecem nos textos utilizados para o processo de ensino-aprendizagem. Como afirma Torres "a sobreposição das relações de poder e das relações de saber, adquire no exame uma dimensão visível; torna-se, desta forma, em um veículo de imposição, definição e legitimação do saber autêntico; define tanto o que conta como conhecimento digno e aceitável, como também quem é o que tem a última palavra ou, o que é o mesmo, o verdadeiro poder" (TORRES, 1991, p. 44). O exame é um efeito das concepções sobre a aprendizagem.

Outros pesquisadores optaram por estudar os ensaios (essays) redatados por alunos na zona soviética na Alemanha depois da segunda guerra mundial. Benita Blessing localizou uma coleção de 1358 ensaios do ano 1946 que giravam em torno de trinta temáticas e afirma de suas fontes o que nós pretendemos transmitir neste trabalho, sobre as nossas (os cadernos escolares): "I do not argue for the privileging of pupils' essays over other, traditional materials. Rather, I hope here to have identified these materials $\mathrm{s}$ an underused, valuable resource in the historical examination of classrooms and young peoples' experiences for any historical period" (BLESSING, 2007, p. 766). 


\section{As coleções de cadernos escolares}

O caderno escolar, por natureza um produto escolar pessoal, vinculado a períodos de aprendizagem e infância, não se encontra em coleções bibliotecárias. É um objeto de estudo de difícil acesso, pertencendo mais ao âmbito pessoal e íntimo de seu autor, que do público ou pesquisador. Inclusive os exames escolares têm mais possibilidades de permanecer arquivados em um centro escolar, por motivos de revisão, reclamação, inspeção e consulta, que os cadernos escolares. O Centro de pesquisa MANES possui na atualidade mais de 150 cadernos $^{7}$ provenientes de quatro doações que fomos recebendo ao longo dos anos. São cadernos que correspondem a distintas épocas históricas que vão desde os anos 1930 até a atualidade.

Os cadernos analisados formam parte da coleção da pós-guerra espanhola em Madri, pertencente ao arquivo "Pilar Ruiz Va" (MARTÍNEZ; MAHAMUD, 2011) ${ }^{8}$.

O arquivo é uma doação que abrange um período histórico desde princípios do século XX até os anos 1960 e está composta de vasta documentação pessoal (folhas de serviço, jornais, revistas e recortes de imprensa, folhas de avaliação de alunos, cartas e desenhos) e outro tipo de material (manuais e cadernos escolares, textos para a formação de professorado, manuais de pedagogia), que facilitam e enriquecem a reconstrução do contexto a que pertencem os cadernos, dando corpo a sua história e existência.

O legado consta de 51 cadernos que abarcam desde os anos 1930 até a década de 1960, ainda que a maioria sejam os cadernos que compõem a pós-guerra espanhola, especialmente das décadas de quarenta e cinquenta. O presente trabalho aprofunda sobre os estudos realizados até agora com uma variedade de produções escolares englobadas dentro do que é amplamente considerado como caderno escolar, mas cuja diferente tipologia é manifesta. O denominador comum que possuem estas fontes é o fato de pertencer à mesma família. São cadernos conservados por duas gerações de professores.

1) Os diários de classe, também conceituados como cadernos rotativos ${ }^{9}$, da professora Pilar $\mathrm{Va}^{10}$, no grupo escolar José Echegaray ${ }^{11}$ durante os anos quarenta e no grupo escolar Patriarca Obispo Eijo Garay ${ }^{12}$ durante os anos cinquenta, a meninas entre doze e catorze anos, quer dizer, dos graus superiores da escola primária.

\footnotetext{
${ }^{7}$ Não é possivel estabelecer o número exato pois muitos estão em processo de catalogação.

${ }^{8}$ Agradecemos sempre a professora Pilar Ruiz Va pela doação do arquivo pessoal de seus pais e avós, professores nacionais. Sobre este arquivo pessoal e os arquivos pessoais como fontes documentais na pesquisa da história da educação.

${ }^{9}$ Os cadernos de "rotación", de "circulación" ou de "classe" são cadernos em que participam todas as alunas da classe. Cada dia uma delas se encarrega de realizar algumas atividades práticas (geralmente duas) selecionadas entre as lições da jornada.

${ }^{10}$ Oriunda de Alesanco, Logroño. Licenciada em Filosofia e Letras pela Universidad Complutense de Madrid.

${ }^{11}$ Grupo Escolar José Echegaray. A pesquisa nos conduziu a 1934 como ano em que se declara "oficialmente criada no Grupo "José Echegaray", situado na Rua de Serrano, número 46, desta capital, uma Escola Nacional graduada de seis Seções de meninos e outras tantas de meninas, com direção única a cargo do Professor, a base das seis Escolas de cada sexo que no referido Grupo venham funcionando [...] “ ("Gazeta de Madrid", n. 34 de 3 de fevereiro de 1934, p. 916).

${ }^{12}$ O Grupo Escolar Patriarca Obispo Eijo Garay era uma escola de meninas de Madrid situada na Rua López de Hoyos. Existe atualmente como colégio público. Foi fundado no início dos anos 50 como centro piloto. A etapa do maternal era a mais experimental.
} 
2) Os cadernos de classe e individuais dos alunos do professor Manuel Va Zaldivar nos anos quarenta, no grupo escolar Joaquín Costa.

3) Os cadernos de deveres de Pilar Ruiz Va, nos anos cinquenta, também no Grupo Escolar Patriarca Obispo Eijo Garay.

Os objetivos concretos do estudo, partindo do exposto na introdução, são, por um lado, comprovar se os professores utilizaram manuais escolares em sua tarefa diária em sala de aula, quais utilizaram e como o fizeram, e, por outro, examinar o tipo de exercícios que mostram a produção escolar.

\section{Evolução da pesquisa sobre os cadernos escolares do arquivo "Ruiz Va"}

Dividimos em quatro as fases ou etapas da pesquisa realizada com cadernos escolares como fontes complementares ao manual escolar dentro do Centro de pesquisa MANES.

1) O caderno como objeto de estudo.

2) Os vestígios dos manuais nos cadernos.

3) A diversificação na pesquisa: conteúdos específicos e primeiros estudos comparados.

4) A renovação metodológica.

Respondem à evolução da pesquisa e ao processo de indagação sobre a fonte documental.

\subsection{O Caderno como objeto de estudo: o início da pesquisa}

Como pesquisadoras do Centro de pesquisa MANES, especialistas na análise de manuais escolares, nossa primeira aproximação a esta nova fonte documental tinha o objetivo claro de conhecê-la a fundo. Para isto realizamos uma análise dos cadernos, a maneira de uma radiografia, que nos permitiu familiarizar-nos com a fonte e conhecer suas características, tanto externas como internas.

Nossos objetivos iniciais de pesquisa foram averiguar quem, para quê e por quê se usa o caderno, assim como conhecer a estrutura interna dos conteúdos, prestando atenção às matérias e aos exercícios. Fruto desta primeira aproximação à fonte, surgiu uma primeira publicação (BADANELLI; MAHAMUD, 2008) na que, além de nos determos em sua materialidade, analisamos a diagramação e apresentação dos conteúdos, nos aproximamos de sua estética, especialmente por meio dos desenhos que ilustram suas páginas, e realizamos uma primeira aproximação ao estudo dos conteúdos detendo-nos especialmente nos elementos que definem a formação política e religiosa.

No seguinte exemplo, mostramos a organização dos conteúdos nos cadernos escolares rotativos:

1) Data: a professora começa sempre com a data completa, exceto o dia da semana. 
2) Matérias e programação: continua indicando o nome das matérias e o que vai trabalhar em cada uma delas. Em ocasiões, antes desta breve e resumida programação, introduz uma ordem.

3) Manuais e materiais: em terceiro lugar, mas não de forma sistemática, menciona os manuais escolares, os autores e outro tipo de material didático com o que vai trabalhar.

4) "Exercícios de aplicação": atividades realizadas pelas alunas, que assinam ao final de seu trabalho.

5) Anotações da professora: é frequente também, mas não sistemático, a anotação de observações gerais - não necessariamente pedagógicas - por parte da professora ao fim do dia, a continuação do trabalho das alunas.

Fig. 1. Caderno escolar (1944).

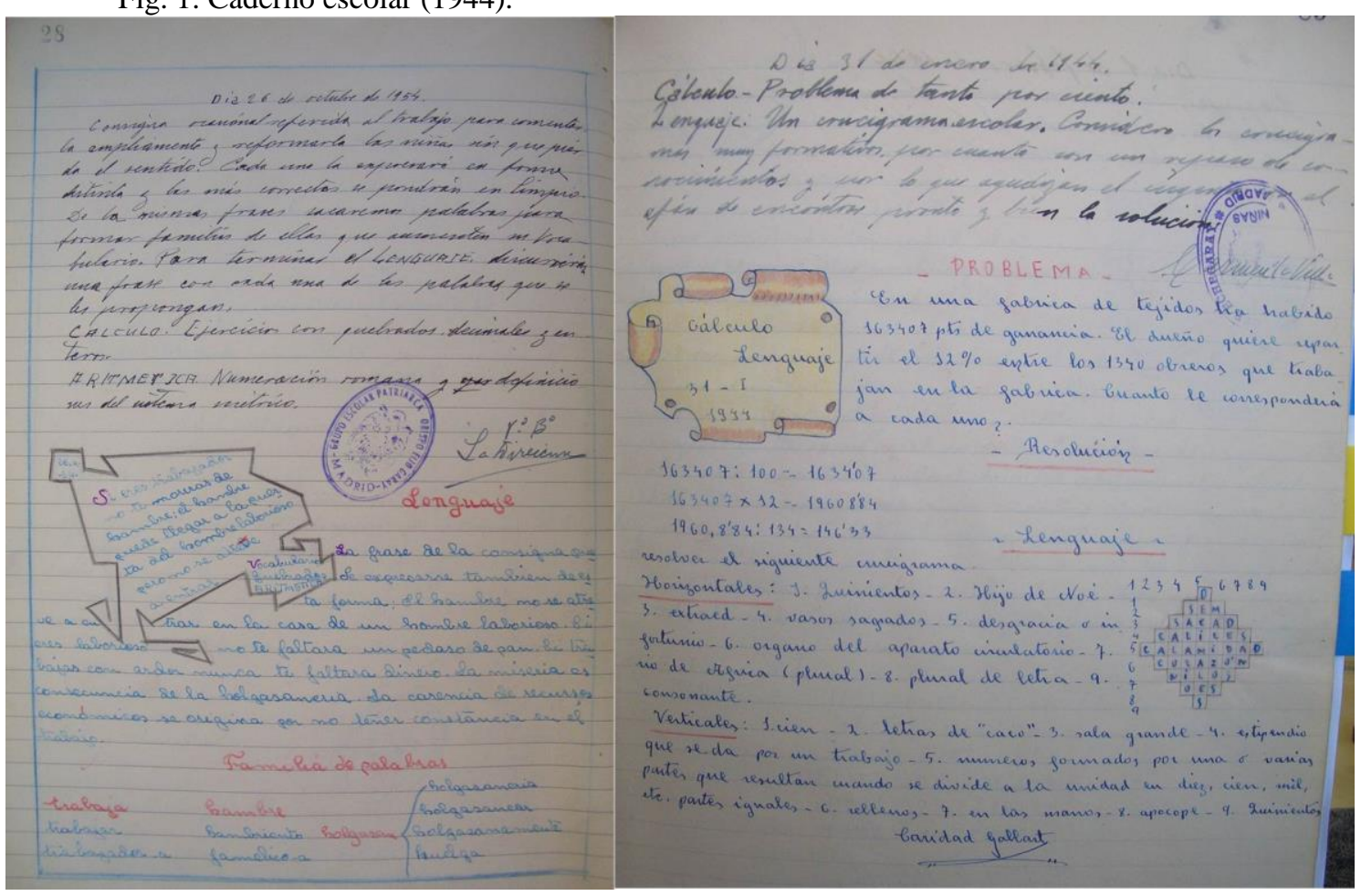

Fonte: [Universidade Nacional de Educação a Distância, Centro de Pesquisa MANES]

Deste primeiro trabalho surgiram como acontecimentos evidentes a participação da professora como coautora do caderno, porque realmente se tratava de um diário e registro de suas classes e da sobressalente questão estética. Ambos elementos requeriam uma análise própria e pormenorizada. 
Fig. 2. Caderno escolar (1947).

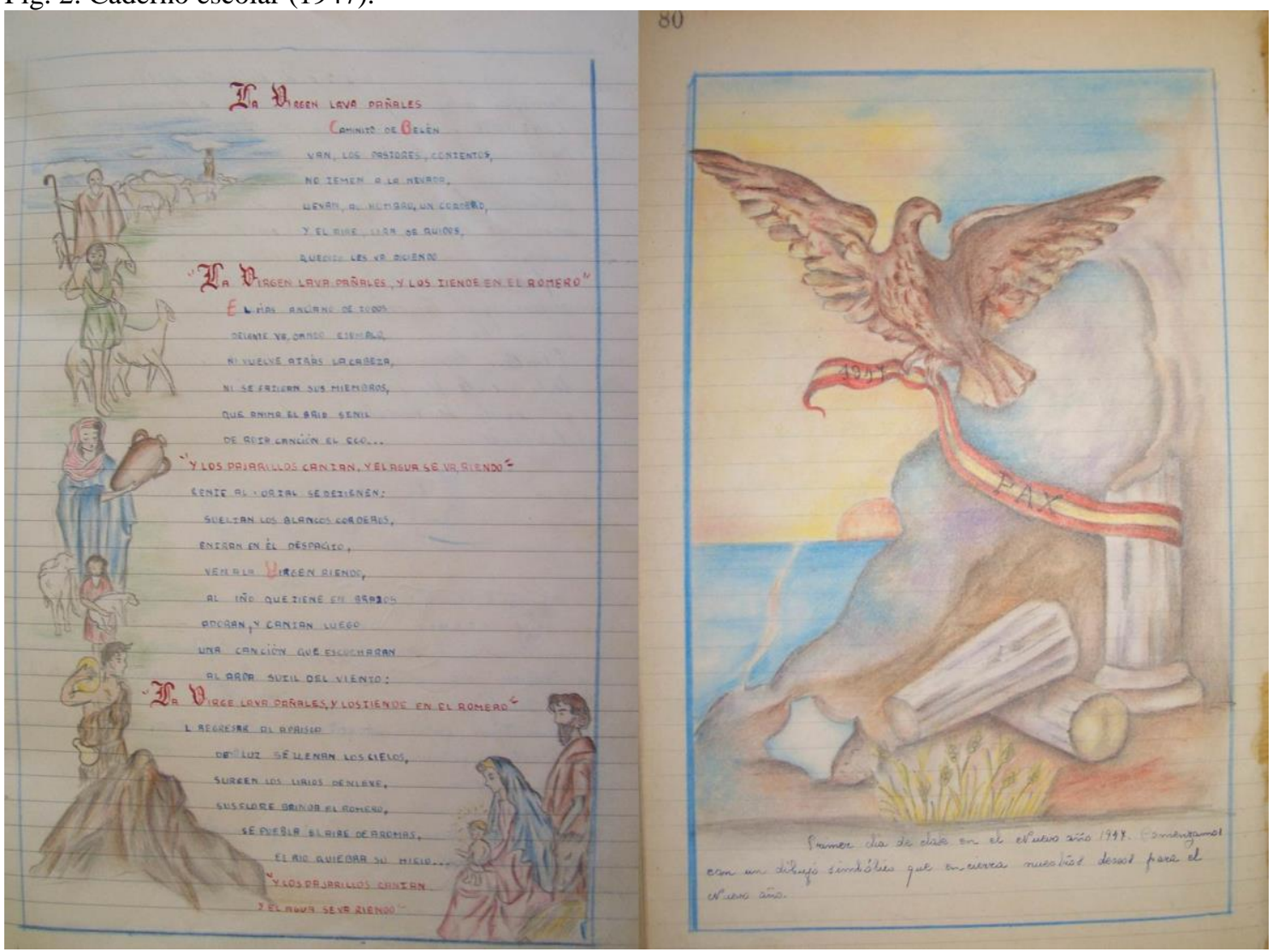

Fonte: [UNED, MANES]

Os novos valores ideológicos do regime impregnam cada página e emergem de forma explícita. Tanto os conhecimentos escolares como os comentários e anotações da professora revelam ideias e valores patrióticos e católicos, mas ao mesmo tempo foi possível descobrir certas licenças por parte da professora na seleção de conteúdos, como a redução ao mínimo de ensinos considerados exclusivamente femininos.

Os resultados destas primeiras análises foram fundamentalmente descobrir as possibilidades investigativas que estas fontes nos oferecem dentro dos campos da manualística e da cultura escolar. Os cadernos são um acúmulo de práticas escritas de ensino e aprendizagem, de intermediação docente e recepção do discente, mas não concluídas, e sim em processo. No salto do manual para o caderno não só aprofundamos na intencionalidade educativa, mas também nos aproximamos à participação do professor no caderno como uma amostra de sua docência e ao tipo de implicação do aluno.

\subsection{O vestígio dos manuais nos cadernos escolares}

Nosso segundo trabalho foi o cotejo paralelo entre ambas as fontes: manuais escolares representativos e os reflexos ou manifestações expressas que aparecem deles 
em diversos cadernos escolares. O objetivo desta análise era pesquisar o vestígio dos manuais escolares nos cadernos através da prática da escrita e no processo de aculturação das meninas. Este trabalho de constatação e análise do uso direto e real do manual escolar requeria a busca (nos manuais) das ilustrações e dos textos escritos por alunas (nos cadernos). Uma vez encontradas a imagem e o texto analisamos se haviam sido extraídos literalmente ou se haviam sofrido alguma alteração. Também analisamos o uso que a professora fazia da referida imagem ou texto, respondendo assim se se aprofundava na mensagem (e em caso afirmativo, o modo em que se realizou); se, pelo contrário, se centrava mais no estudo da gramática ou se chamava mais à imaginação (BADANELLI; MAHAMUD, 2007). A fórmula de busca foi seguir a classificação de exercícios tradicionais da prática da escritura marcada pela própria professora.

Tipo 1: Cópia

Tipo 2: Ditado

Tipo 3: Redação (individual e coletiva)

Tipo 4: Exercícios sem especificar

Tipo 5: Outros usos

Tipo 6: Cópia da ilustração

O primeiro que descobrimos foi toda uma série de manuais escolares citados pela professora que nos permitiu elaborar uma lista com os textos utilizados.

Ao descobrir que os manuais escolares mais usados pela professora foram Flores de Santidad, Glorias imperiales, Cordialidades y Yo soy español, chegamos a eles para completar a segunda parte do trabalho: o cotejo paralelo entre ambas as fontes, os manuais escolares representativos e os reflexos ou manifestações expressas que deles aparecem nos cadernos. Através desta comparação confirmamos não só o uso de determinados manuais não citados, mas como eram trabalhados seus conteúdos pela professora e pelas alunas. Na continuação mostramos alguns exemplos onde se pode apreciar o uso do manual e da transposição ao caderno pela mão das alunas.

No primeiro exemplo mostramos uma lição ocasional dada com motivo do falecimento do poeta Manuel Machado, em 19 de janeiro de 1946.

Fig. 3. Caderno escolar (1943). 


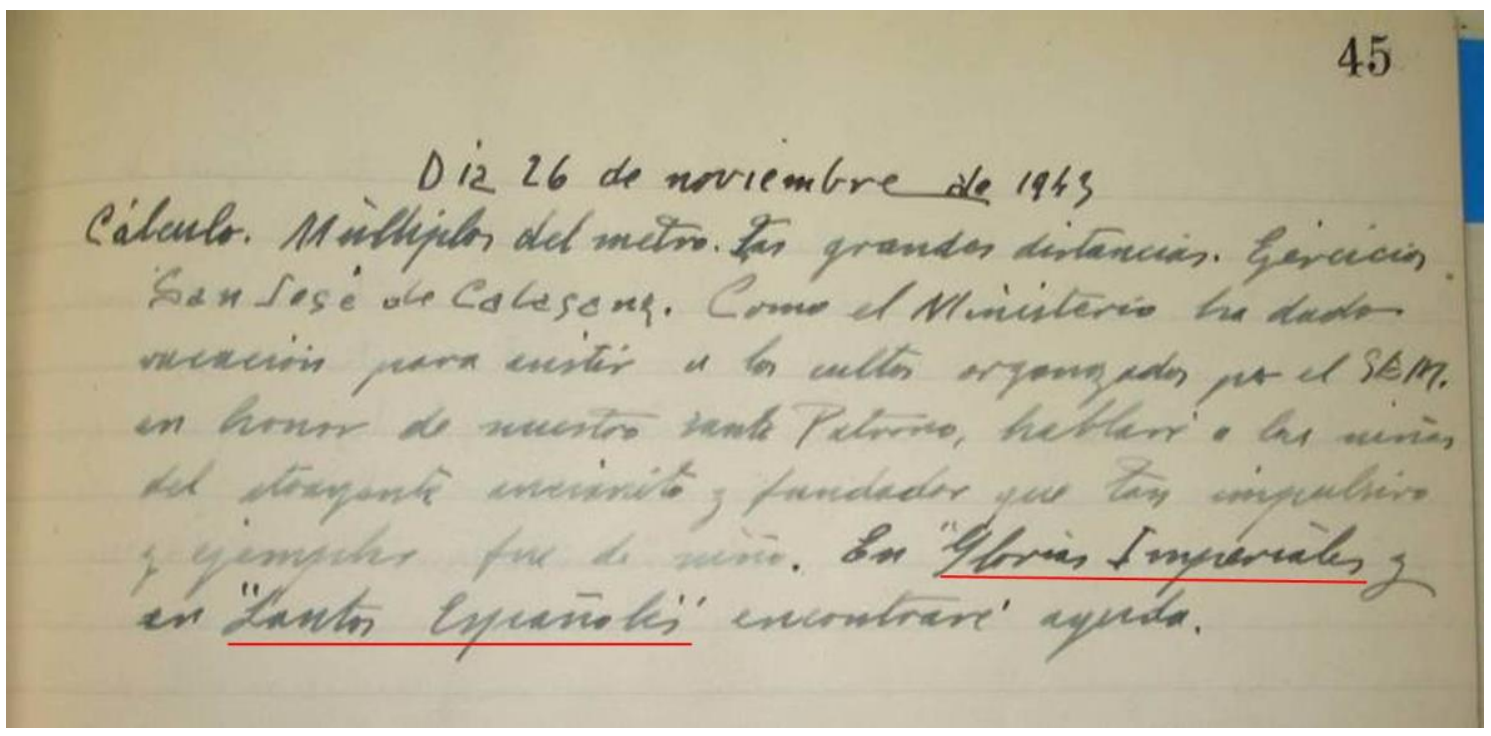

Fonte: [UNED, MANES]

A professora, na programação, escreve: "Comemoração em honra de Manuel Machado q.e.p.d. Falaremos de seu espanholismo e leremos poesias. Como a melhor homenagem a sua glória copiarão duas poesias, uma de tom religioso e outra patriótica. Outro grande poeta que se vai". A bibliografia que indica é Suma poética de Pemán e Herrero e Las mil mejores poesías de Bergua. Acrescenta que os desenhos serão tomados de Cordialidades. Os dois primeiros manuais citados não deixaram vestígios no caderno; todavia, identificamos tanto o texto como o desenho no livro Cordialidades.

A Figura 4 mostra o texto da poesia Castilla na letra gótica, extraída da página 40, que copiam as alunas literalmente (ilustração do meio). A ilustração da direita mostra o desenho extraído da página 50 do mesmo manual. A professora, portanto, selecionou dois elementos diferentes de um mesmo manual para formar um exercício.

No segundo exemplo observamos como é realizada uma cópia fiel do texto e imagem da poesia La hermana (Figura 5). Neste caso a professora especifica o tipo de exercício que vão realizar e o manual que vão utilizar: Cordialidades.

Os ditados são outra das atividades práticas que mais contém estes diários de classe. O ditado foi estudado por outros pesquisadores, como Eliane Peres, que descobre diferentes formas de corrigir os ditados que parte dos professores e como no ano 2000, se segue empregando o tradicional exercício escrito da escola primária baseando-se na teoria construtivista de alfabetização (PERES, 2012).

Fig. 4. Caderno escolar (1946) e A. Fernández Rodríguez, Cordialidades: antologia lírica escolar, Barcelona, Miguel Ángel Salvatella, 1943, pp. 40 e 50. 


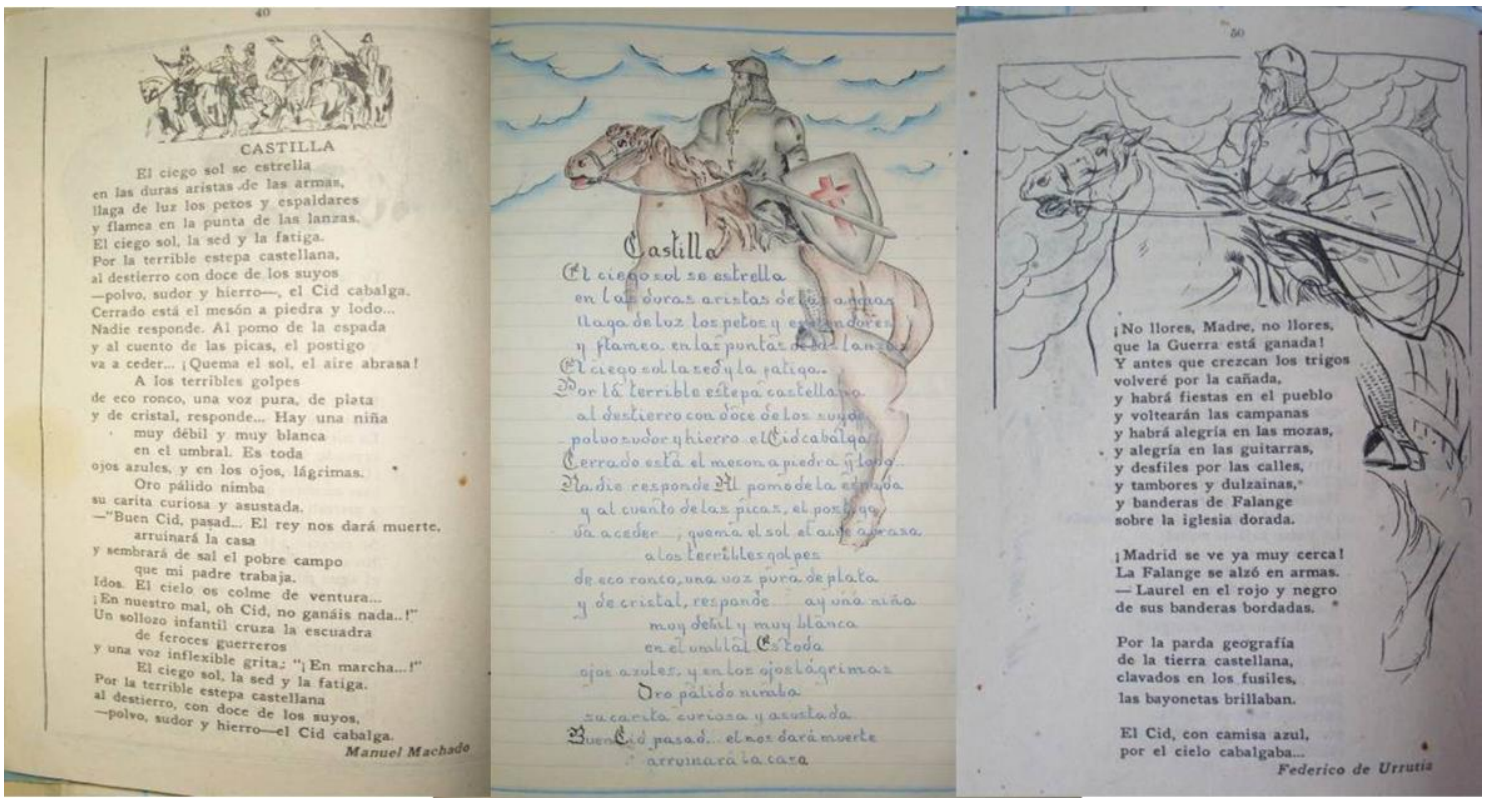

Fonte: [UNED, MANES]

Fig. 5. Caderno escolar (1946) y A. Fernández Rodríguez, Cordialidades: antologia lírica escolar, Barcelona, Miguel Ángel Salvatella, 1943.
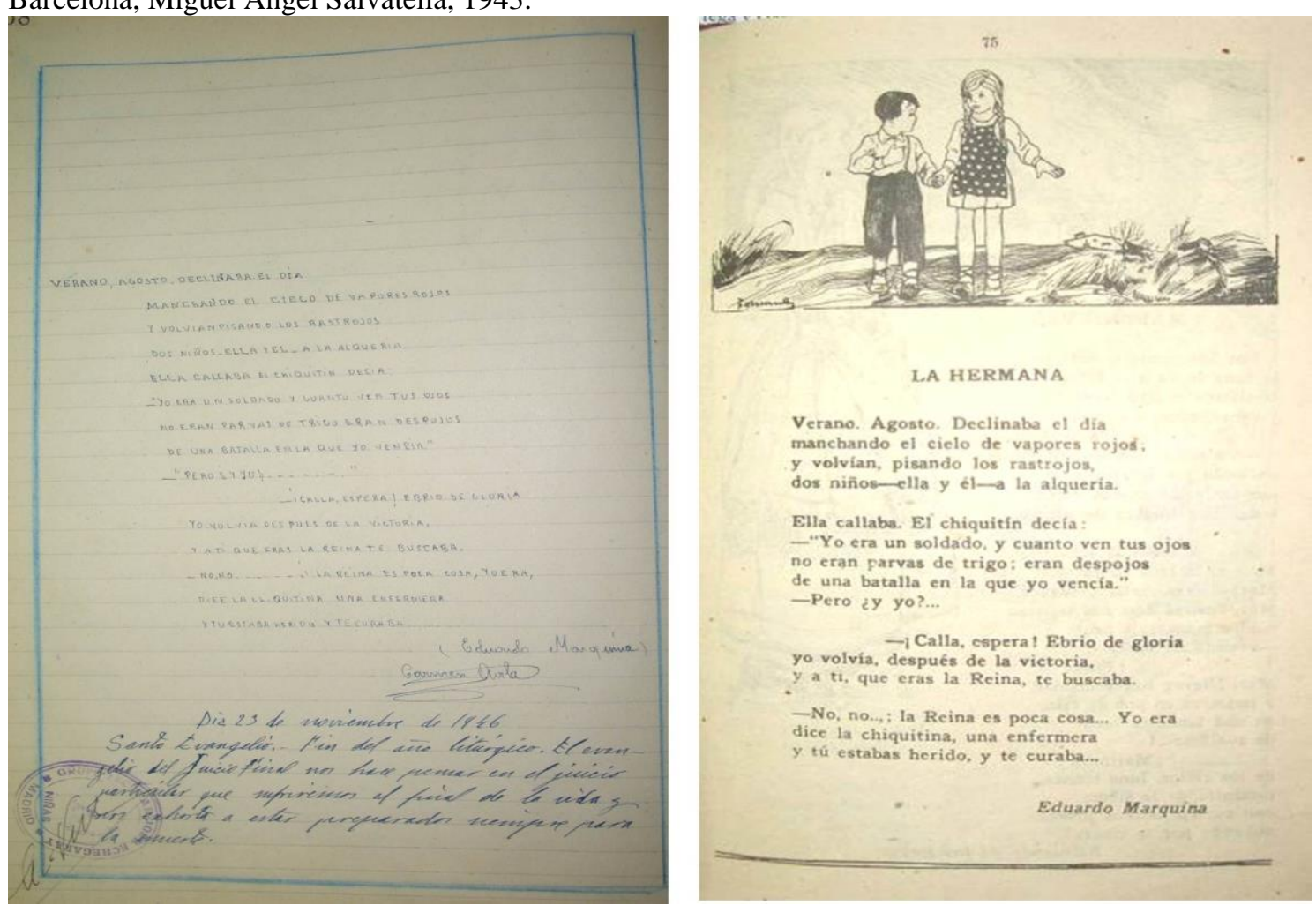

Fonte: [UNED, MANES] 
Fig. 6-7. Caderno escolar (1954) e A. Serrano de Haro, Espanha é assim, Madrid, Escola Espanhola, 1949 (4. Ed.), p. 188 e 189.

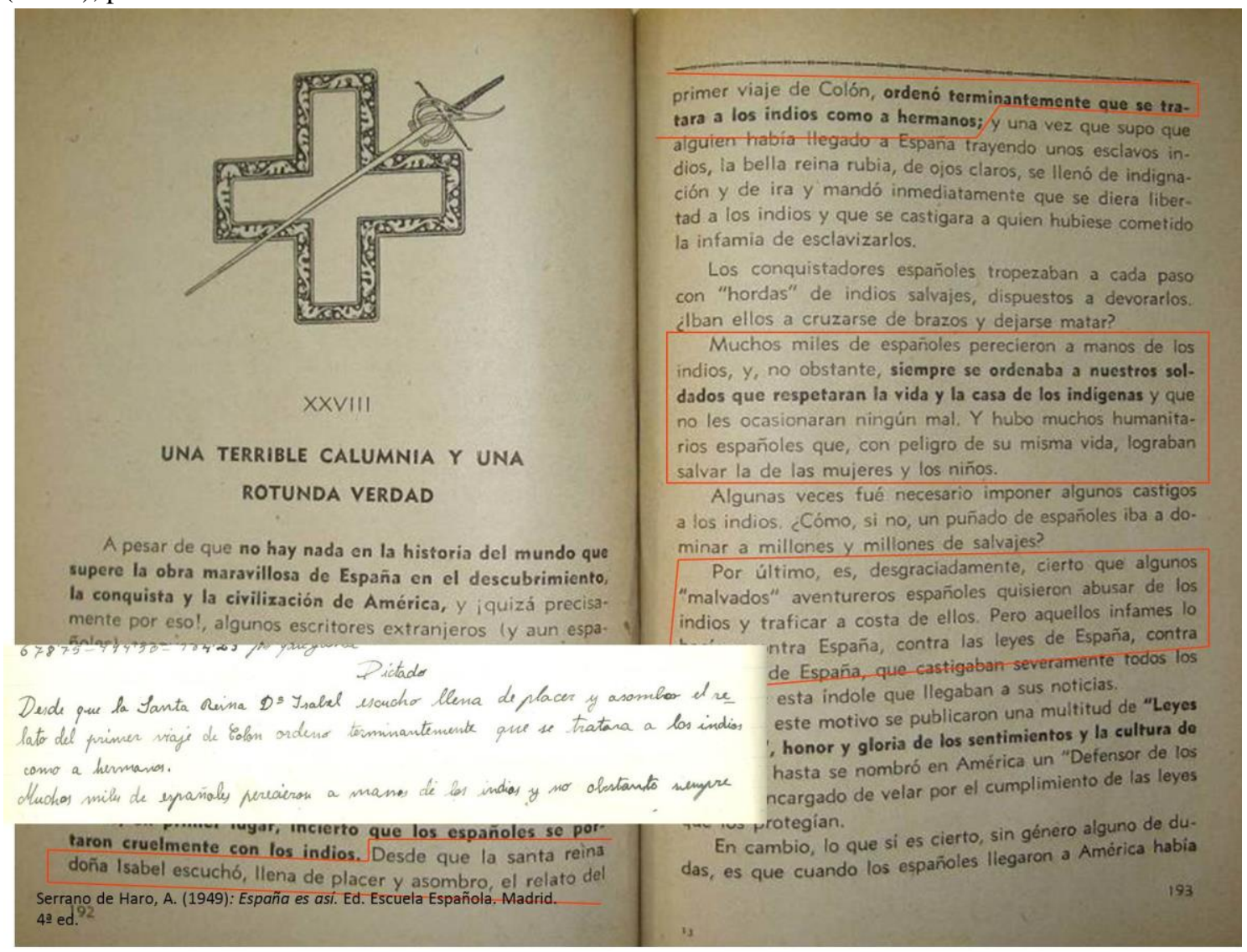




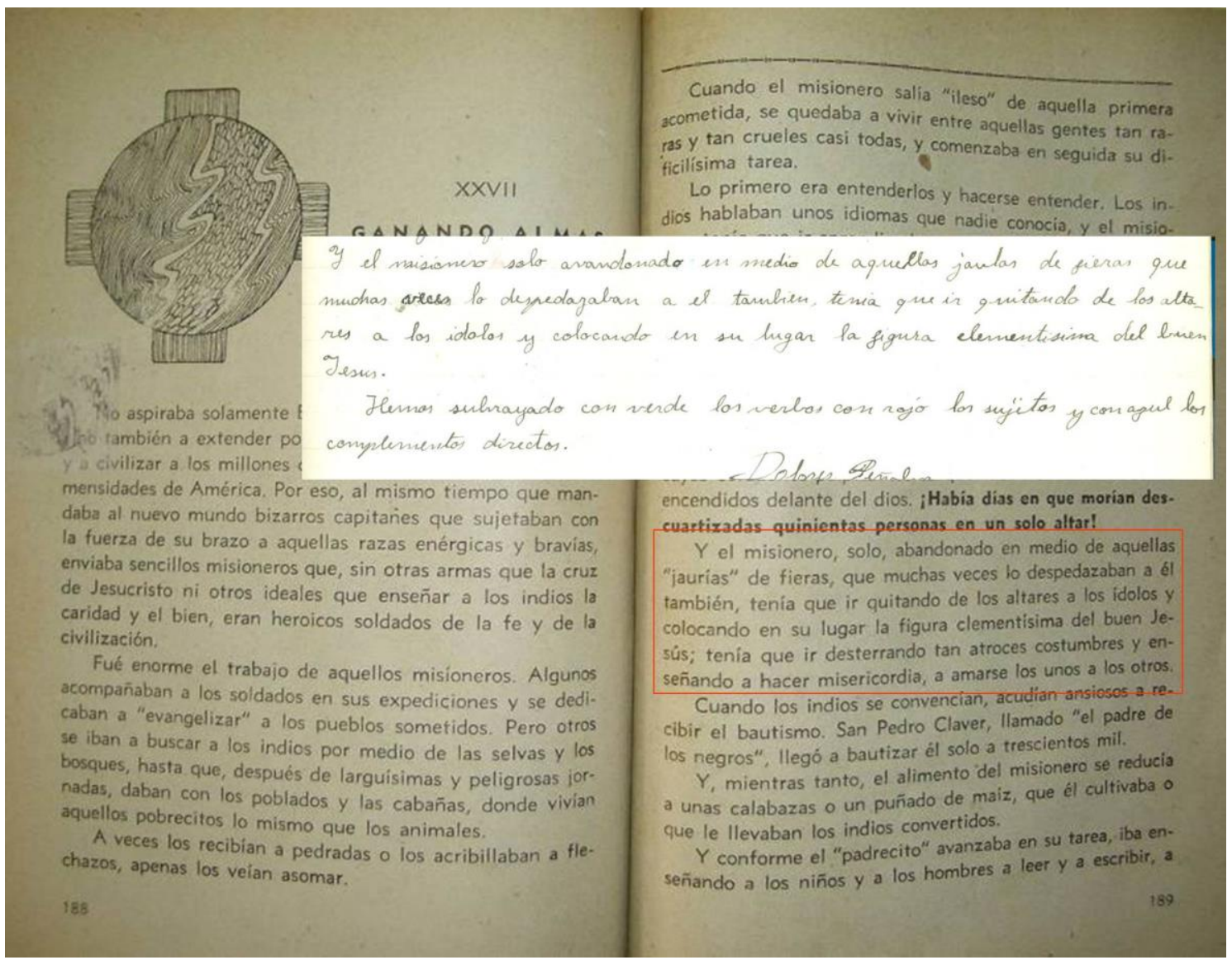

Fonte: [UNED, MANES]

Em nossos diários, existem diversas variedades de ditados. Em seguida mostramos um exemplo de ditado múltiplo, quer dizer, o ditado é extraído a partir de diferentes textos do manual e inclusive de diferentes capítulos e descobrimos como a professora seleciona os textos que formarão parte do exercício.

Em outras ocasiões, o ditado é fiel a um parágrafo completo do manual e a cópia da ilustração que acompanha o texto é extraída também do mesmo manual e capítulo. 
Fig.8. Caderno escolar (1954) e L. Ortiz Muñoz, Glorias Imperiales. Libro escolar de lecturas históricas: t. 2, Madrid, Magistério Espanhol, 1940 (5. ed.).

La exploración del Nuevo Mundo y su geografía fué en verdad tan obra de los soldados, como de los misioneros. Las rutas de los conquistadores dejaban regiones inmensas, serranias abruptas, barrancos y ríos que sólo contemplaban en la lejanía. Los que las trillaban con sus pies, las que las recorrian palmo a palmo y las fijaban definitivamente en los mapas, eran los frailes que no buscaban el oro ni la gloria, sino almas para Jesucristo y súbditos cristianos para el Imperio.
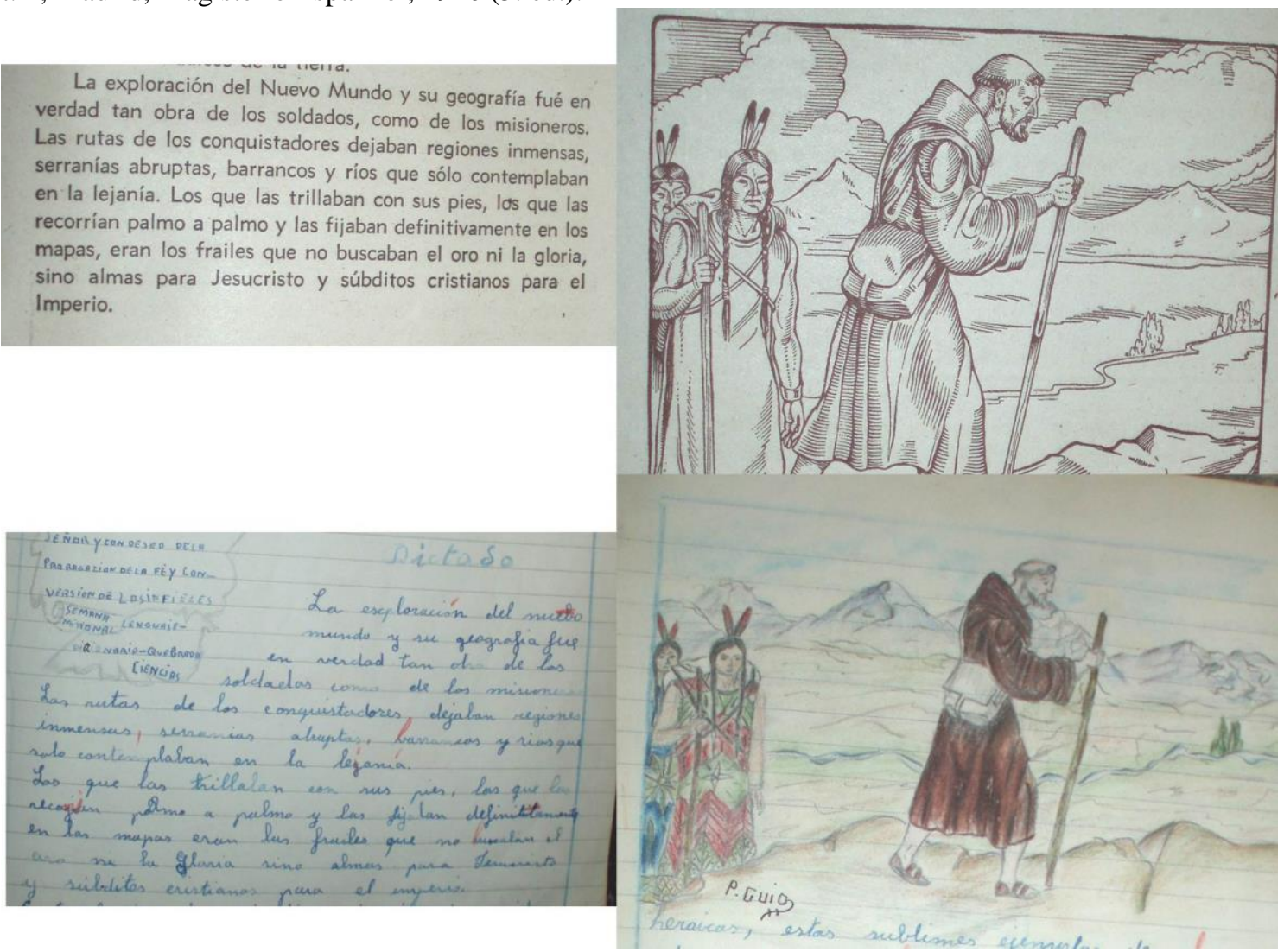

Fonte:[UNED, MANES] 
Fig. 9. Cuaderno escolar (1954) y Enciclopedia Elemental, Madri, Sessão Feminina da Falange Espanhola Tradicionalista (FET) e das Juntas de Ofensiva Nacional-Sindicalista (JONS), 1946.

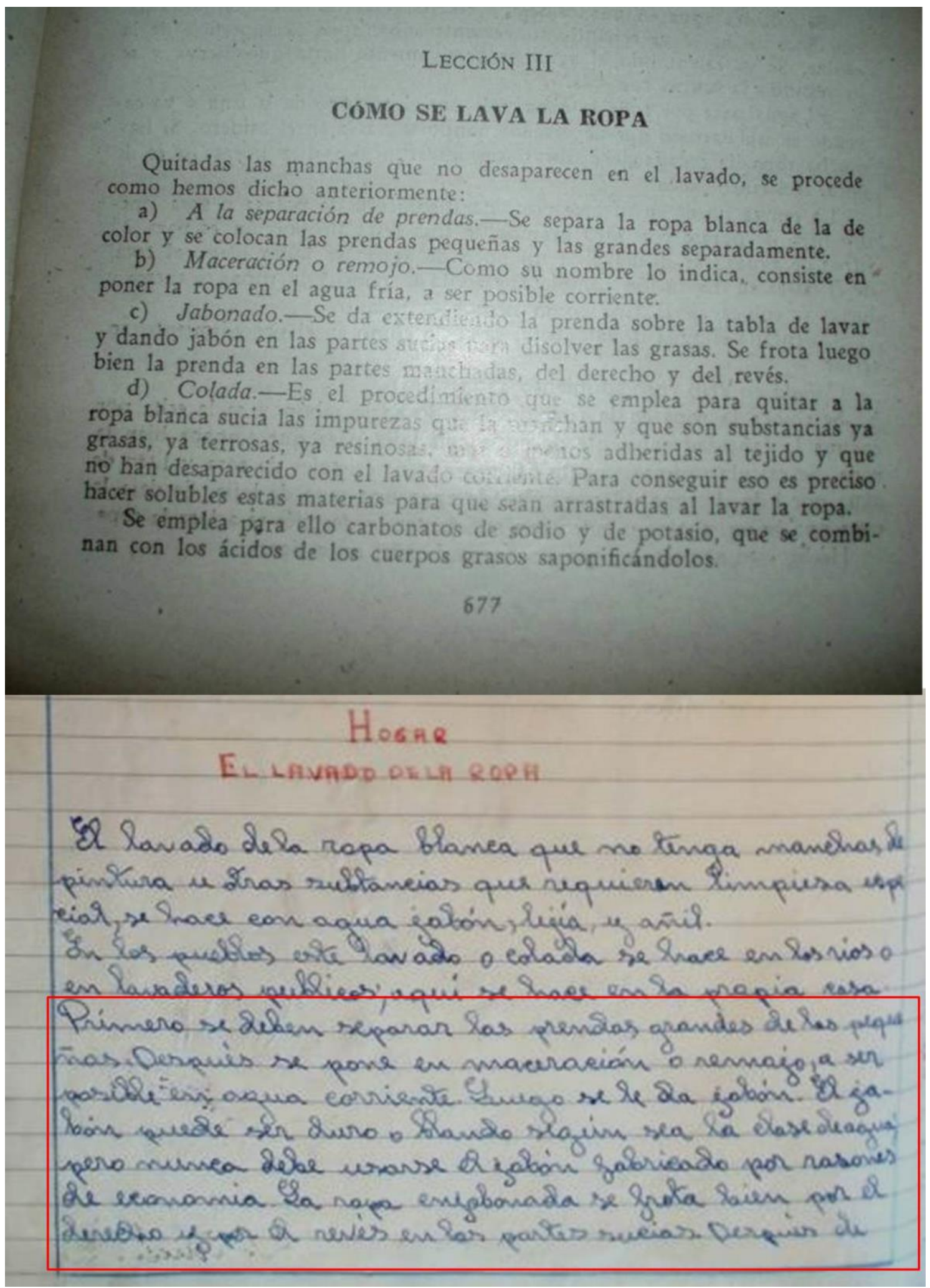

Fonte:[UNED, MANES] 
Fig. 10. Caderno escolar (1955) e J. García e Fernández-Castañón, Flores de Santidad, Madri, Escola Espanhola - filhos de Ezequiel Solana, 1945, p.20.
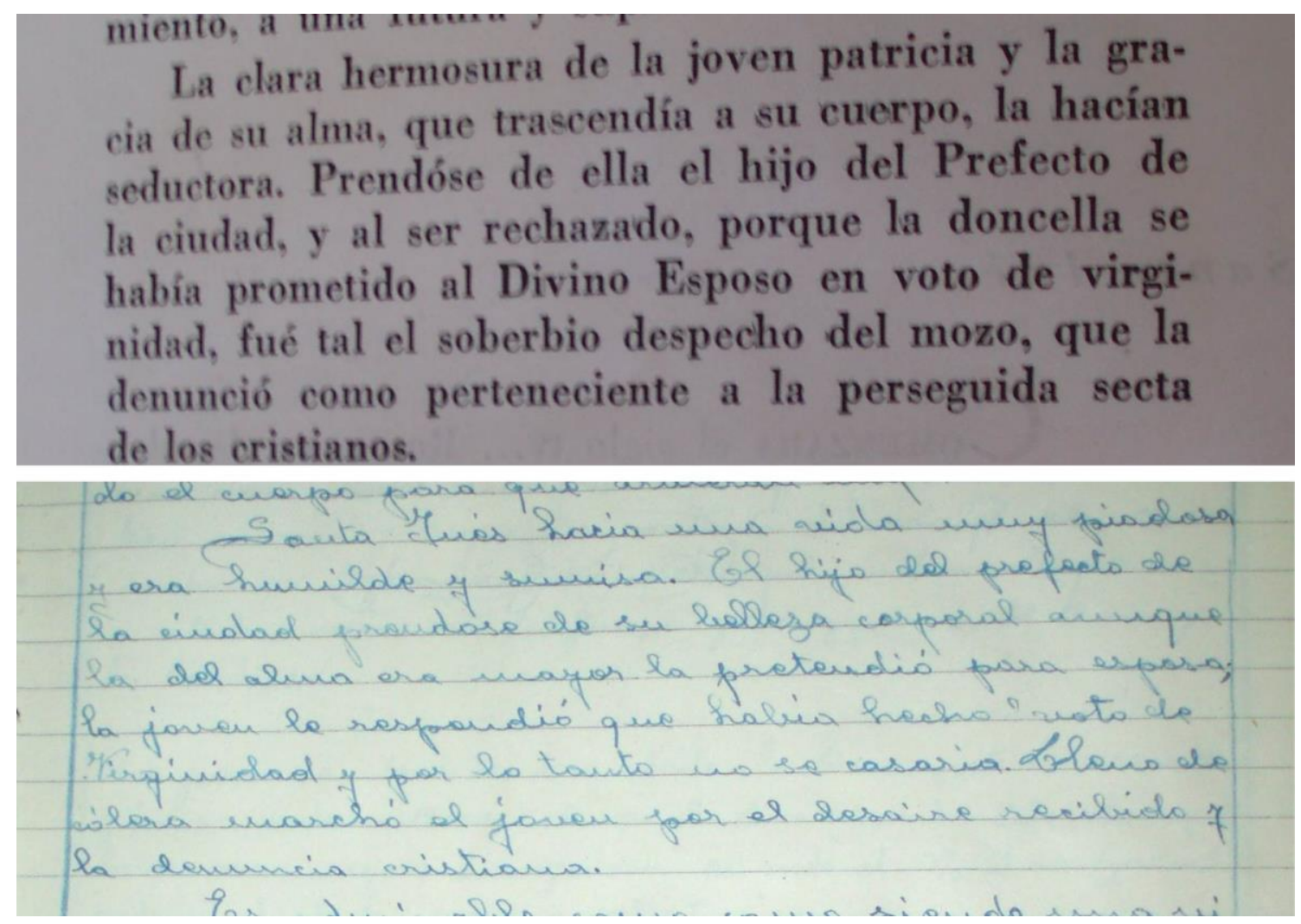

Fonte: [UNED, MANES]

Fig. 11. Caderno escolar (1953) e J. García e Fernández-Castañón, Flores de Santidad, Madri, Escola Espanhola - Filhos de Ezequiel Solana, 1945, p. 28.
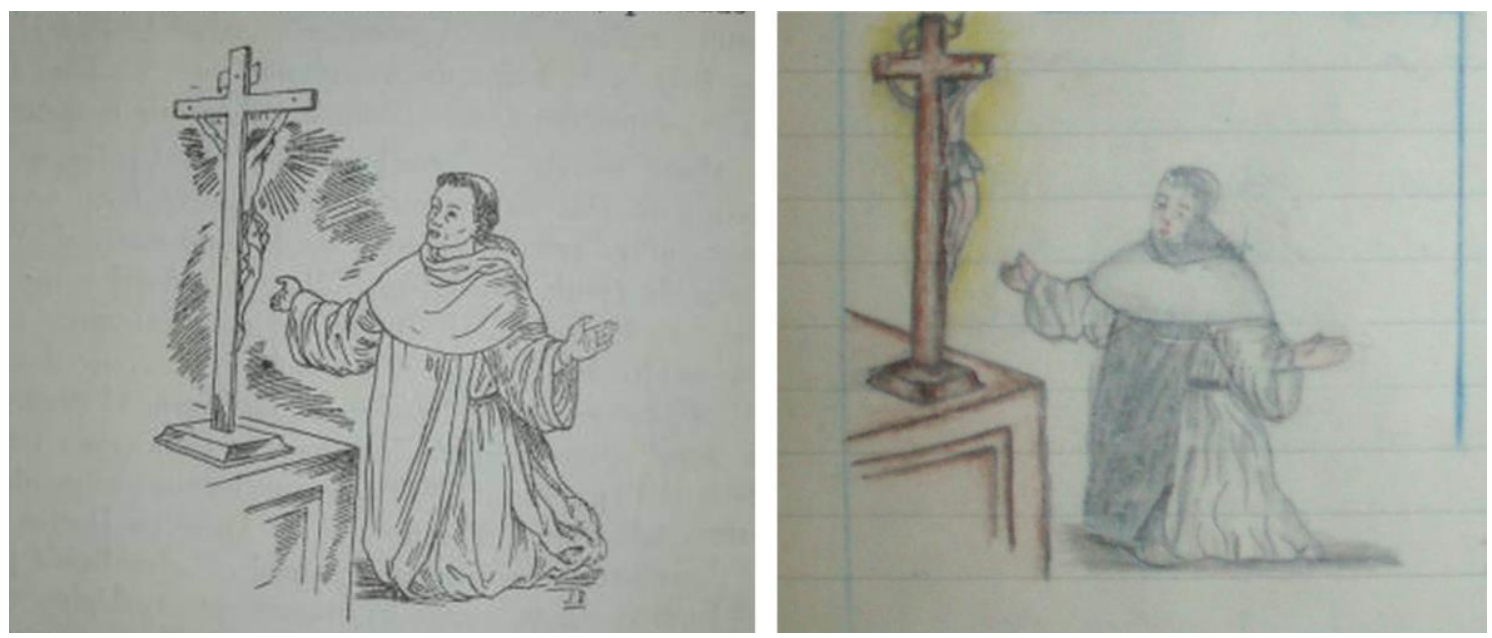

Fonte:[UNED, MANES]

Outro tipo de exercício é o que a própria professora denomina "ditado resumo". Neste caso a professora modifica e adapta um texto do manual para construir o ditado (Figura 9).

Outro tipo de exercício amplamente usado que requer com frequência recorrer ao manual escolar é a redação. No exemplo que mostramos em seguida se descobre 
como a aluna realiza uma interpretação própria de um texto do manual na sua redação individual. Ao comparar minuciosamente as duas fontes vemos que no caderno aparece o mesmo conteúdo e o mesmo vocabulário que no manual, neste caso Flores de Santidad, mas redigida de forma diferente (Figura 10).

Outro uso do manual, cujo rastro é evidente nos cadernos, refere-se ao seu uso como fonte inspiradora de ilustrações. Estas formam parte da programação da professora. Quer dizer que, existe um tempo específico para a realização desta tarefa como objetivo escolar em si mesmo. Os cadernos escolares estão inundados de desenhos tirados diretamente dos manuais. Não são produtos da criatividade das meninas, são cópias quase exatas de ilustrações complexas, mas mostrando uma grande habilidade e alto nível de percepção e esmero artísticos (Figura 11).

No exemplo seguinte nos apercebemos de como se seleciona de uma imagem aqueles elementos que dão sentido ao conteúdo da lição. Observamos que a lição trata do missionário espanhol Fray Juan Ramírez e não do descobrimento da América. Ao copiar o desenho a aluna omite a figura de Cristóvão Colombo cravando a bandeira espanhola em terras americanas.

Fig. 12. Caderno escolar (1959) e A. Serrano de Haro, Yo soy español, Madrid, Escola Espanhola - Filhos de Ezequiel Solana, 1957 (17. ed.), p. 62.

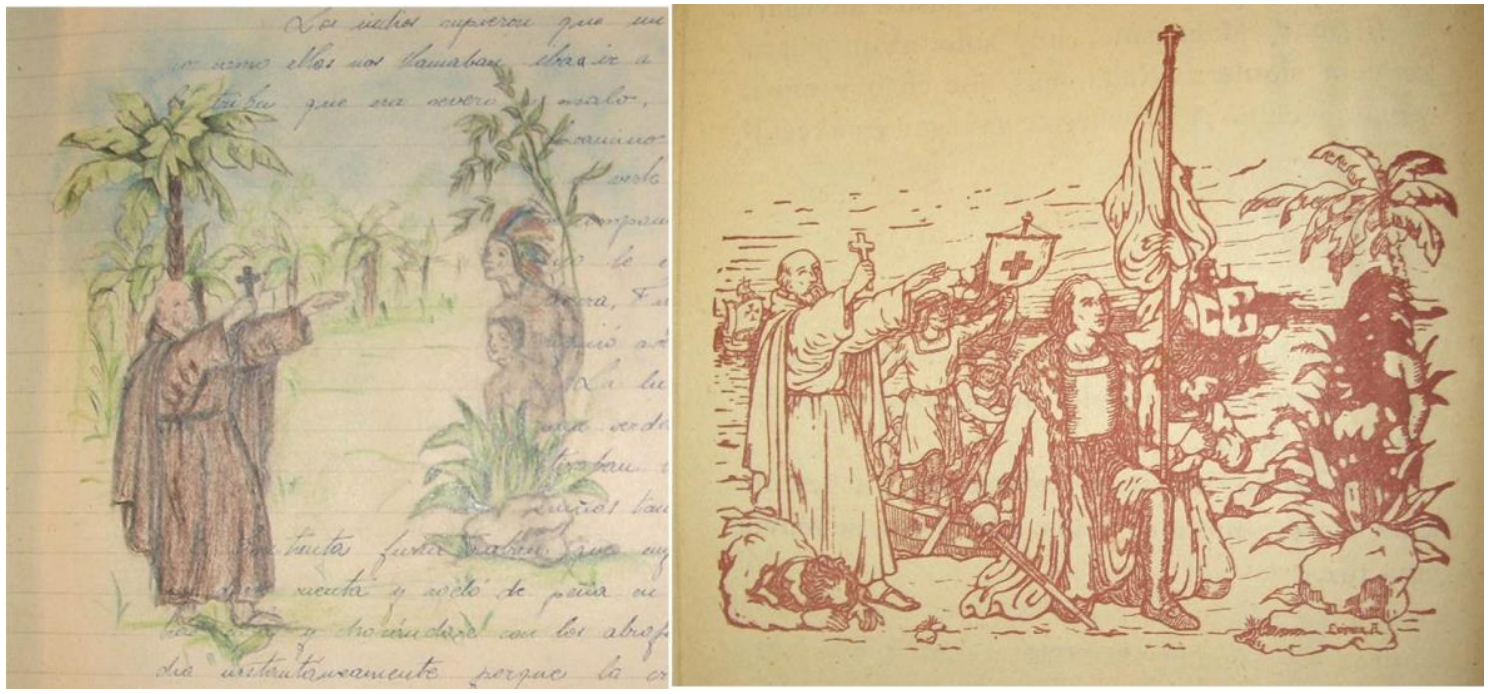

Fonte: [UNED, MANES]

Como resultado deste trabalho confirmamos o fato de que existe um ensino da escrita baseado nas tradicionais fórmulas de entretenimento da expressão escrita, mas também a relevância outorgada à expressão icônica. Em ambos os casos, apesar das possibilidades de criatividade expressiva serem praticamente nulas, as meninas são capazes de fazer visível sua aplicação na tarefa, sua habilidade e bem fazer.

\subsection{Diversidade da pesquisa: conteúdos específicos e primeiros estudos comparados}


Como terceiro passo, decidimos abordar o estudo independente de conteúdos diversos e específicos presentes nos cadernos escolares, por um lado, e começar a analisar os primeiros cadernos escolares em comparação com outros. Era importante passar a estas questões para comprovar dois pontos cruciais na pesquisa com as novas fontes: primeiro, quanto davam de si os documentos, quais outras informações proporcionavam e segundo, comprovar até que ponto eram singulares os primeiros cadernos escolares analisados, pelas características anteriormente mencionadas.

Ocupamo-nos dos aspectos emocionais, por um lado, e dos estéticos e das ilustrações por outro. Realizamos a análise dos cadernos a partir de um enfoque incomum e centrando-se em um objetivo aparentemente difuso e escorregadio: resgatar e destacar a presença de conteúdo emocional atendendo a três elementos concretos e diferentes - ainda que convergentes - do trabalho docente:

1) a sinceridade e transparência da professora na hora de expressar seus próprios sentimentos e sua alusão à importância do sentimento dentro da aprendizagem;

2) as referências ao amor pátrio e religioso, em especial mas não exclusivamente, nas lições de comemorações;

3) o recurso à poesia para o ensino de conteúdo linguístico, geográfico, histórico e religioso (MAHAMUD, 2008).

Comprova-se neste trabalho o conteúdo emocional presente nas lições da professora, na transmissão da ideologia e nas relações entre a professora e suas alunas. Desta análise se infere que a professora concebe o caderno rotativo como um recurso e um material educativo, desde o momento em que para ela a escrita - apesar de tratar-se de escritas impostas, padronizadas, "disciplinadas e dirigidas pelos docentes" serve "como veículo de comunicação de conhecimentos, ideias, e sentimentos". Não é, portanto, um dispositivo exclusivo de controle e inspeção, mas também de aculturação do escrito e de doutrinação ideológica por meio do conhecimento e do sentimento.

Por outro lado, como já dissemos anteriormente, estes cadernos têm a peculiaridade de estar cheios de ilustrações e desenhos realizados pelas próprias meninas. Como dado quantitativo relevante, no caderno de 1953, de 117 dias programados pela professora, as ilustrações aparecem em 84 ocasiões, o que indica que $71 \%$ do total dos dias registrados foram dedicados aos desenhos. Ainda assim, mais que a quantidade de ilustrações, algo que é comum encontrar neste tipo de fonte, e apesar de tratar-se de um exercício de cópia, chama a atenção a qualidade excepcional das reproduções. Surpreende o aspecto estético não só pelos desenhos que aparecem, mas também pela ordem, a limpeza, o cuidado da caligrafia, das margens e do uso do espaço e da cor. Sua correta realização era um objetivo escolar a mais. A estética e o "bom gosto" incidem diretamente no trabalho diário, de tal forma que os conteúdos estéticos se convertem em uma parte importante da prática escolar. Frequentemente aparecem ilustrações que estão sem terminar e inclusive espaços em branco destinado a desenhos, o que indica que formavam parte da programação junto com o resto das atividades que se realizariam nesse dia. Em alguns casos, inclusive aparece como tarefa programada "terminar a ilustração do dia anterior" (BADANELLI, 2008, p. 246).

Os passos seguintes tomaram caminhos divergentes: iniciar uma pesquisa comparativa (BADANELLI, 2010), entre diferentes tipos de cadernos e pôr em 
evidência o trabalho docente da professora (MAHAMUD, 2010) através de suas anotações, instruções e correções. O primeiro trabalho pretendeu realizar um estudo comparado entre os cadernos rotativos ou diários e os individuais de deveres com o objetivo de descobrir semelhanças e diferenças entre uns e outros atendendo a três aspectos: aos conteúdos que apresentam tendo em conta as disciplinas e matérias que se observavam em ambos, ao tipo de exercícios ou atividades que realizam as alunas nos dois tipos de cadernos, analisando assim as distintas práticas escolares de escrita, e, por último, à forma como os conteúdos e as atividades são apresentados nos cadernos, prestando atenção a distribuição do espaço, a apresentação, a estética e as ilustrações que se incluem. A comparação de conteúdos e aspectos estéticos lança luz sobre a melhor qualidade dos trabalhos e a maior variedade de conteúdos nos cadernos de classe que nos de deveres, os quais se centram, fundamentalmente, na linguagem e cálculo.

O segundo estudo analisou de forma comparada a atividade docente dos professores e o trabalho de alunos e alunas, como produção e mostra de rendimento escolar, em cadernos individuais e coletivos de crianças e os diários da professora Pilar Va. O objetivo, neste caso, era averiguar até que ponto se trata de dispositivos ou instrumentos pedagógicos de controle, homogeneizados e homogeneizantes, criados para garantir uma efetiva inculcação da arbitrariedade cultural que se pretende reproduzir. A atividade de sala de aula e a docência do professor ficam refletidas no caderno, sobretudo através das anotações dos professores, confirmando que formam parte da autoria do documento escolar e que existe um controle da produção infantil que conduz não só a obediência docente, no que diz respeito à transmissão da ideologia do regime, mas também à aplicação de critérios pedagógicos do bom trabalho escolar e de exigências de rendimento em aprender o estipulado e se aplicar na apresentação dos trabalhos escolares.

\subsection{A renovação metodológica}

Estudar a fundo alguns cadernos como objetos de estudo (o que contém, como se organiza a informação, quem participa dele e como), combinar os cadernos com manuais escolares (encontrando evidência da presença de uso do segundo), analisar conteúdos específicos como são a questão estética, as ilustrações, o conteúdo emocional e o trabalho docente, comparar diferentes tipos de cadernos (os de classe individuais com os coletivos e estes com os de deveres, assim como os de meninas com os de meninos), formava parte da análise interna dos cadernos escolares. A natureza das produções escolares coletadas no tipo de suporte selecionado tinha que ser analisada minuciosamente. Contudo, as próprias fontes, os diários, cadernos de classe, individuais e de deveres, também nos conduziram aos autores e centros escolares de onde procediam. Ou seja, a fonte escrita e o estudo dos conteúdos e escrituras, nos levaram a outros elementos de análises, o humano e o institucional.

Fomos percebendo que as características do arquivo "Ruiz Va" permitiam conduzir uma pesquisa de maior alcance. $\mathrm{O}$ fato de tratar-se de um arquivo pessoal e familiar, e não só de uma recopilação de cadernos descontextualizados, abria a porta a uma investigação mais ampla e compreensiva. Os numerosos cadernos que dispúnhamos têm as assinaturas de alunos e alunas. Na busca por localizar várias destas pessoas nos encontramos com três delas, o pintor e Catedrático de Belas Artes da Universidade Complutense de Madri, Antonio Zarco, seu irmão Fernando e a ex- 
diretora da biblioteca do Instituto de Educação da Universidade de Alcalá, Pilar Alcalá, assim como com a filha e neta dos professores. Ninguém melhor que os próprios protagonistas para falarmos de seus trabalhos nos cadernos escolares e de uso dos manuais.

Iniciando a investigação por meio de fontes orais, passamos a entrevista-los e descobrimos que seus testemunhos completavam muitas das lacunas da pesquisa sobre as fontes escritas: como se trabalhava no caderno, que grau de orientação e liberdade de expressão tinha o aluno, que prática escrita predominava até que ponto refletia o estudado na aula através do manual, a frequência de revisão por parte do professor, o acompanhamento dos pais... Aprendemos também que os testemunhos orais, como toda fonte, não está isenta de problemas, e neste caso, se tratava e se tratam das limitações e condicionantes próprios da memória e do sentimento, aspectos que condicionam a percepção de tempos e experiências pretéritas.

Alguns dos achados e confirmações de suspeitas teóricas por meio das entrevistas foram os seguintes: o caderno rotativo era considerado um diário e participar era um prêmio, os trabalhos estavam totalmente dirigidos e não havia possibilidade de expressão pessoal, os cadernos viajavam da escola para casa e serviam para estudar a lição para o dia seguinte, ao modo do manual escolar. Ou seja, seus conteúdos se convertiam na lição que deveriam memorizar. Ao falar sobre o caderno, Antonio Zarco, um dos meninos que assina os trabalhos, remetia sempre a conversa ao professor e ao centro escolar ${ }^{13}$. Este fato é significativo porque demonstra o papel predominante do professor sobre o trabalho escolar: dava instruções precisas sobre o que se devia incluir no mesmo e os acostumou a incluir sempre um desenho em cada lição escrita, a trabalhar de forma sistemática e valorizar a ordem e a estética.

A renovação metodológica, portanto, aponta para as combinações de variadas fontes escritas e a inclusão das orais. É nesta abertura onde se abrem e cruzam linhas de pesquisa e enfoques interdisciplinares. Do estudo dos manuais escolares, ao incorporar os cadernos, abrimos o caminho para as histórias de vidas de professores e alunos, entrando no campo da micro-história; mas também à história dos centros escolares, cujos diretores e professores deixaram uma marca clara.

\section{Considerações finais sobre a necessidade de uma investigação combinada de}

\section{fontes primárias}

O trabalho evidenciou a existência de certa trajetória em micro-estudos sobre cadernos escolares em combinação com livros didáticos, e que estes confirmam que a análise dos livros didáticos não deveriam limitar-se a examiná-los como "emissores" de mensagens, códigos e conteúdos que devem ser decifrados, porque também é preciso conhecer o uso que se fez deles em sala de aula e, sobretudo, acercar-se da apropriação de suas mensagens por parte dos sujeitos que aprendem. No momento de interpretar o alcance de sua influência, o rigor metodológico exige que se estudem dentro do conjunto das práticas da sala de aula e se verifique, por meio de diferentes indicadores, o uso efetivo que se deu aos textos escolares (OSSENBACH, 2010).

\footnotetext{
${ }^{13}$ Neste caso se trata do Colégio Joaquín Costa de Madri, ao qual também se considerou alguns trabalhos relacionados com o arquivo, os professores e os alunos.
} 
Para ajudar a resolver este problema propomos uma maior contextualização do manual dentro da sala de aula por meio do estudo combinado com outras fontes primárias complementares. Estas podem ser várias e diversas, provenientes de várias áreas contextuais. Mas uma das chaves está em ir além das leis e do curriculum, emitidos pelas autoridades e demais agentes dos contextos de produção e entrar em contato com aquelas fontes provenientes dos contextos de recepção. É certo que estas podem ser diversas e que cada uma delas têm suas potencialidades e limitações.

No entanto, nossa pesquisa defende a importância e o potencial do caderno escolar como fonte primária complementar ao livro didático, idônea para responder àquelas perguntas que o livro por si só não pode dar resposta. Os cadernos escolares e fontes similares nos permitem averiguar o impacto que tiveram os manuais escolares, e em certa medida, o uso e consumo que se fez deles. A história destes documentos reflete a história do modo de atuar da escola, dos diferentes projetos educativos e dos diversos papéis desempenhados por professores e escolares em processo conjunto de ensinoaprendizagem. Na combinação paralela entre ambas às fontes, os manuais escolares efetivamente utilizados e os reflexos ou manifestações expressas que deles aparecem nos cadernos, se descobre a vinculação entre as políticas educativas gerais e as práticas efetivas de aula, ou de sala de aula, ou seja, a relação entre as práticas de produção e as práticas de recepção da mensagem escolar, passando pelas ações, os suportes e os agentes que midiatizam e impregnam a comunicação.

É evidente que a implantação do caderno como dispositivo pedagógico responde a um momento de troca na história da escola e dos métodos de ensino/aprendizagem caracterizado pela complementariedade que, desde finais do século XVIII, foi ocorrendo entre a escrita e a leitura. Somos conscientes de que os cadernos escolares seguem sendo, neste sentido, testemunho do que se pretende ensinar e do que se trabalha em sala de aula e que não indicam necessariamente o que realmente se aprende. Constituem fontes documentais de intenções educativas, como são os livros escolares, mas mais próximos à etnografia da escola. A diferença se apoia no fato de que com eles avançamos vários passos qualitativos porque não só complementamos o livro escolar, mas adentramos em como se desenvolve na prática escolar a dita intencionalidade educativa.

É certo que por outro lado, não podemos deixar de perguntarmos até que ponto se trata de outro dispositivo ou instrumento pedagógico a mais, de controle, homogeneizado e homogeneizante - recorrendo a Bourdieu -, criado para garantir uma efetiva inculcação da arbitrariedade cultural que se pretende reproduzir. Mas por outro lado, não cabe dúvida de que entramos na produção escolar real, de mãos dadas com os alunos e as alunas. E mais, a atividade de sala de aula fica refletida no caderno através de alunos e professores, não só os primeiros, porque ambos deixam rastros e partilham autoria. Os cadernos são testemunho de práticas, exercícios e experiências dirigidas e compartilhadas, em que também há ao menos um mínimo de produção e criação própria que surge no próprio processo de elaboração da tarefa.

Não obstante, temos seguido o conselho ou advertência de Dominique Julia quando alerta da necessidade de indagar e estudar práticas culturais que muitas vezes não deixam rastros (JULIÀ, 1995). Efetivamente, para executar a tarefa de reconstruir a vida em sala de aula há que buscar novas fontes "não convencionais" e recorrer à etnografia da escola que nos permita reconstruir os contextos (escolares e extraescolares) de uso dos manuais escolares (ROCKWELL, 2009). Por esse motivo, saltamos das fontes escritas às fontes orais, completando a pesquisa combinada de 
manuais e cadernos com os testemunhos das meninas e meninos, agora adultos, que assinavam os trabalhos escolares e estudavam os manuais escolares. O estudo da cultura escolar por meio de manuais e cadernos nos conduziu ao cruzamento de caminhos entre as pesquisas sobre manualística, práticas escolares, prática docente, histórias de vida e histórias de centros escolares, manifestando a inter-relação dos elementos que formam o campo educativo e a necessidade de enfocar os estudos desde a contextualização e combinação das fontes e desde a interdisciplinaridade das ciências sociais e da educação.

\section{REFERÊNCIAS}

BADANELLI, Ana María. A estética e as ilustrações nos cadernos escolares: o caso de uma escola de meninas na Espanha franquista. In: MIGNOT, Ana Chrystina Venancio (Org.). Cadernos à vista: Escola, memória e cultura escrita. Rio de Janeiro: Ed. UERJ, 2008, p. 7-13.

Cuadernos de rotación, cuadernos de deberes: un estudio comparado.

In: Meda, Montino, Sani (eds.), School Exercise Books, 2010, v. II, p. 793-802.

BADANELLI, Ana María; MAHAMUD, Kira. Cuadernos escolares: un ejemplo de la práctica de la escrita escolar en el franquismo, In: GÓMEZ, C (dir.), Sierra Blas (ed.), Mis primeros pasos, 2008, p. 259-279.

La huella de los manuales escolares en la cultura escrita: um estudio de caso en la escuela franquista. In: Fernández, J.; TOCINO; MIRANDA, G. E. M. B. (eds.), La escuela y sus escenarios. Puerto de Santa María, Ayuntamiento de El Puerto de Santa María, 2007, p. 207-228.

BARRIGA, Ángel Díaz. Una polémica en relación al examen. Revista Iberoamericana de Educación, 5, 1994, p. 161-181.

BECCHI, Egle. La historia de la infancia y sus necesidades de teoría. In: DÁVILA, P.; NAYA, L. M. (coord.), La infancia en la historia: espacios y representaciones, Donostia, Espacio Universitario EREIN, 2005, vol. I, p. 21-38.

BLESSING, Benita. Methodological Considerations: Using Student Essays as Historical Sources. The Example of Postwar Germany. Paedagogica Historica, 6, 2007.

DEPAEPE, Marc; SIMON, Frank. Fuentes y métodos para la historia del aula. In: M. Ferraz Lorenzo (ed.), Repensar la Historia de la Educación, Nuevos desafios, nuevas propuestas, Madrid, Biblioteca Nueva, 2005.

. Manuels scolaires belges 1830-1880. Répertoire établi à partir de quatro collectoins, Bruselas, Arquives générales du Royaume, 2003.

EADs., Dilectics in a branch of historiofraphy, "Annali di storia dell'educazione e delle istituzione scolastiche", 12, 2005, p. 107-123. 
Los cuadernos escolares de clase como reresentaciones simbólicas de la cultura escrita escolar, In: Eguizábal, J. A. J.; et al. (coords.), Etnohistoria de la escuela. XII Coloquio Nacional de Historia de la educación, Burgos, SEDHEUniversidad de Burgos, 2003, p. 653-664.

Prácticas de escritura en los cuadernos escolares españoles (19201940). In: MEDA, J.; MONTINO, D.; SANI, R.; (eds.), School Exercise Books. A Complex Source for a History of the Approach to Schooling and Education in the 19th and 20th Centuries, Firenze, Polistampa, 2010, vol.. II, p. 823-845.

Representaciones de la escuela y de la cultura escolar en los cuadernos infantiles (España, 1922-1942). In: GÓMEZ, A. G. (dir.), V. Sierra Blas (ed.), Mis primeros pasos. Alfabetización, escuela y usos cotidianos de la escritura (ss. XIX-XX), Gijón, Trea, 2008, p. 213-242.

VIÑAO FRAGO, Antonio. Escuela graduada y exámenes de promoción: necesidad endógena o imposición exógena? en La acreditación de saberes y competências, 2001.

Los cuadernos escolares como fuente histórica: aspectos metodológicos e historiográficos. Annali di storia dell'educazione e delle istituzioni scolastiche, 2006, 13, p. 17-35.

HEINZE, Carsten. Historical Textbook Research: textbooks in the Context of the "Grammar of Schooling", Journal of Education Media, Memory and society, 2, 2010.

JULIA, Dominique. La culture scolaire comme objet historique. Paedagogica Historica, Séries Suplementares, 1, 1995.

MAHAMUD, Kira. Labor docente y trabajo escolar bajo el nacional catolicismo franquista (1945-1959). In: MEDA, J.; MONTINO, D.; SANI, R.; (eds.), School Exercise Books, 2010, v. II, p. 747-767.

O conteúdo emocional de três cadernos escolares do franquismo. In: A. C. Venâncio Mignor (org.), Cadernos à vista. Escola, memória e cultura escrita, Rio de Janeiro, Universidade do Estado do Rio de Janeiro, 2008, p. 205-221.

MARTÍNEZ Ruiz-Funes, María José; MAHAMUD, Kira. Los arquivos familiares como fuentes documentales en la investigación histórica-educativa: un estudio de caso. In: CELADA, P. (ed.), Arte y oficio de enseñar. Dos siglos de perspectiva histórica. XIII Coloquio nacional de Historia de la educación, El Burgo de Osna, SEDHEUniversidad de Valladolid, 2011, v. II, p. 709-717.

OSSENBACH, Gabriela. Manuales escolares y patrimonio histórico-educativo. Educatio Siglo XXI, 2010, v. 28, n. 2, p. 115-132.

PERES, Eliane. Um estudo da história da alfabetização através de cadernos escolares (1943-2010). Cadernos de História da Educação, 1, 2012. 
POZO Andrés, María del Mar del y ZAMORA, Sara Ramos. El cuaderno de clase como instrumento de acreditación de saberes escolares y control de la labor docente, en La acreditación, Oviedo, SEDHE-Universidad de Oviedo, 2001, p. 481-501.

POZO Andrés, María del Mar del. El cuaderno de rotación en la cultura popular española. In: Cuaderno del Maestro. Selección de ejercícios del Cuaderno de Rotacion. Escuela de niños n. 2 de arganda del Rey. Años 1922-1932. Maestro: D. Ramón Aparicio Pérez, Aarganda del Rey, Ayuntamiento de Arganda del Rey, 2005.

ROCKWELL, Elsie. Entre la vida y los libros: práticas de lectura en las escuelas de la Malintzi a principios del siglo XX. In: CASTAÑEDA, C; et al. (coords.), Lecturas y lectores en la Historia de México, México, CIESAS - Universidad Autónoma del Estado de Morelos, 2004.

La experiência etnográfica. Paidós, Buenos Aires, 2009.

SOMOZA RODRÍGUEZ, M. El Proyecto MANES y la investigación sobre manuales escolares: un balance crítico de resultados y nuevos desafios. History of Education \& Children's Literature. v. Q, n. 1, p. 431-451, 2006.

TORRES, Jurjo. El curriculum oculto, Madrid, Morata, 1991.

Aprovado:12/03/2017

Recebido:12/04/2017 